\title{
Numerical Experiments on Modeling of the Black Sea Deep Currents
}

\author{
S.G. Demyshev ${ }^{1}$, O.A. Dymova ${ }^{1}$, N.V. Markova1, V.B. Piotukh ${ }^{2}$ \\ ${ }^{1}$ Marine Hydrophysical Institute, Russian Academy of Sciences, Sevastopol, \\ Russian Federation \\ e-mail: n.v.markova@mail.ru \\ ${ }^{2}$ P.P. Shirshov Institute of Oceanology, Russian Academy of Sciences, Moscow, \\ Russian Federation
}

\begin{abstract}
Modeling results of the Black Sea deep-water current reconstruction are considered. Computations are provided by applying the nonlinear z-coordinate model developed in Marine Hydrophysical Institute (MHI). Climatic atmospheric forcing and the atmospheric reanalysis data (ALADIN, EraInterim) obtained for 2006, 2010 and 2013 are taken into account in different numerical experiments. The Black Sea climatology experiment is performed with a spatial grid step equal to $5 \mathrm{~km}$, and in other experiments the $1.6 \mathrm{~km}$ grid step is used. Three-dimensional structure of the Black Sea currents on 45 levels within the surface horizon $(2.5 \mathrm{~m})$ and the bottom one $(2100 \mathrm{~m})$ is reconstructed. The anticyclonic current (countercurrent) extending along the Black Sea continental slope in direction opposite to the Rim Current is detected at about $1000 \mathrm{~m}$ and deeper. In the climatic fields the countercurrent exists in spring and summer in the northern part of the basin. In the experiments that included the reanalysis forcing, the countercurrent is revealed as separate streams in various continental slope areas and in different seasons. Its mean velocity is about $5 \mathrm{~cm} / \mathrm{s}$, the highest one is equal to $10 \mathrm{~cm} / \mathrm{s}$. In the overlying layer in the northeastern part of the Black Sea, the countercurrent is also detected by modeling as well as it is revealed by CTD and $A D C P$ measurements.
\end{abstract}

Keywords: countercurrent, numerical modeling, the Black Sea, deep currents.

DOI: 10.22449/1573-160X-2016-2-34-45

(C) 2016, S.G. Demyshev, O.A. Dymova, N.V. Markova, V.B. Piotukh

(C) 2016, Physical Oceanography

Introduction. The scientists have been particularly interested in the problem of the deep-water anticyclonic current (countercurrent) existence on the horizons under the cyclonic Rim Current for several decades already. In 1942 Neumann formed a hypothesis about the presence of anticyclonic circulation in the deep layers of the Black Sea [1]. He supposed the existence of a two-layer system of currents. The cyclonic direction was in the upper layer to the depth of about $300 \mathrm{~m}$ and the anticyclonic one - on the underlying horizons. The current velocity was assumed to increase at the depth of about $1000 \mathrm{~m}$. Since then, the attempts to prove the presence or absence of the anticyclonic countercurrent had been made by a number of authors from time to time. In the work [2] published in 1995 the possibility of the countercurrent formation in a layer of $100-400 \mathrm{~m}$ in the form of separate streams with velocities of $1-10 \mathrm{~cm} / \mathrm{s}$ was shown. Theoretical and field works in support of a three-layer stratification of the Black Sea waters are given in $[3,4]$. Anticyclonic direction of near-bottom currents was defined in [5]. In the recent years the interest to this problem has been increased again. Due to the intensive development of the ocean models, the opportunity of the qualitative numerical reconstruction of a three-dimensional water dynamics was obtained. For example, within the experiment [6] carried out on the basis of the Bergen model in Moscow State University, the presence of the anticyclonic countercurrent in the climatic fields at a depth of about $1500 \mathrm{~m}$ in the Black Sea waters in all seasons was shown. 
In [7] applying the numerical nonlinear model of Marine Hydrophysical Institute (MHI) [8] the three-dimensional fields of temperature, salinity and currents of the Black Sea with horizontal resolution $5 \mathrm{~km}$ were reconstructed. In [7, 9] the emphasis on climatic hydrophysical fields analysis at the depths below the Black Sea main pycnocline in a layer of $350-1000 \mathrm{~m}$ was made. In these works a number of currents features missed in [10] due to low horizontal resolution $(\sim 15 \mathrm{~km})$ was revealed. To confirm or refute the existence of countercurrent and eddy structures in the field of velocity there had been no available alternative (nonassimilated in the numerical model) data at the time of publication of the works [7, 9].

Currently, the there has appeared the opportunity to compare some of the results obtained in these studies with the field measurements made in the Southern Branch of the P.P. Shirshov Institute of Oceanology RAS (SB SIO RAS) [11], as well as with the reanalysis data [12]. In present research we compare the results of numerical modeling based on the MHI model and available in-situ data at the depths below the main pycnocline.

Experiment I. Parameters. To obtain the three-dimensional fields of temperature, salinity, currents and sea level the system of the ocean hydrodynamics equations including the equations of motion, continuity, hydrostatics, heat and salt advection-diffusion and the equation of state [8] was integrated. To calculate the turbulent viscosity and vertical diffusion coefficients the Pacanowski-Philander approximation is used [13]. In accordance with the method proposed in [14, 15], climatic atmospheric fields were set on the sea surface. In the river mouths and straits fluxes of mass and momentum were taken as given in [16]. Assimilation of the archival climatic temperature and salinity was carried out periodically [17]. Integration time of the model equations was about 1000 days and was determined by achievement of integral characteristics of the quasi-periodic regime.

The calculation was conducted on the 45 vertical horizons corresponding to $2.5-2100 \mathrm{~m}$ depth, horizontal resolution was $5 \mathrm{~km}$, and time step was $5 \mathrm{~min}$.

Analysis of the modeling results. The analysis of the modeling results was carried out. It was found that on $900-1800 \mathrm{~m}$ horizons the anticyclonic current (countercurrent) took place in spring and summer along the continental slope. Fig. 1 shows the direction of this stream. It propagated from the latitude of Varna in the west to the North Caucasian coast in the east. Then it turned to the south-east and proceeded to the central part of the sea along the Anatolian coast. Eventually, it was united with the deep-water anticyclone in the central part of the sea. In the area of the continental slope narrowing (the longitude of Yalta) one of the stream branches turned right and immediately combined with the mentioned anticyclone. Typical velocities in this eddy at the $1800 \mathrm{~m}$ depth were $2-2.5 \mathrm{~cm} / \mathrm{s}$, the maximum ones were about $4 \mathrm{~cm} / \mathrm{s}$. The countercurrent velocities were rather weak, though they were $2-3$ times higher than the background velocity values. The mean velocity was about $1 \mathrm{~cm} / \mathrm{s}$. They increased to $2-2.5 \mathrm{~cm} / \mathrm{s}$ on the continental slope narrowing and reduce to $0.2-0.5 \mathrm{~cm} / \mathrm{s}$ in the areas of its widening. This behavior of currents in the near-bottom zone is described in [5]. On higher horizons in the north-eastern part of the Black sea the countercurrent was characterized by the greater velocity values. Obtained climatic velocity vectors were the mean estimations of the real current magnitude and direction. So, the countercurrent existence in those fields suggests its presence actually in certain periods. 


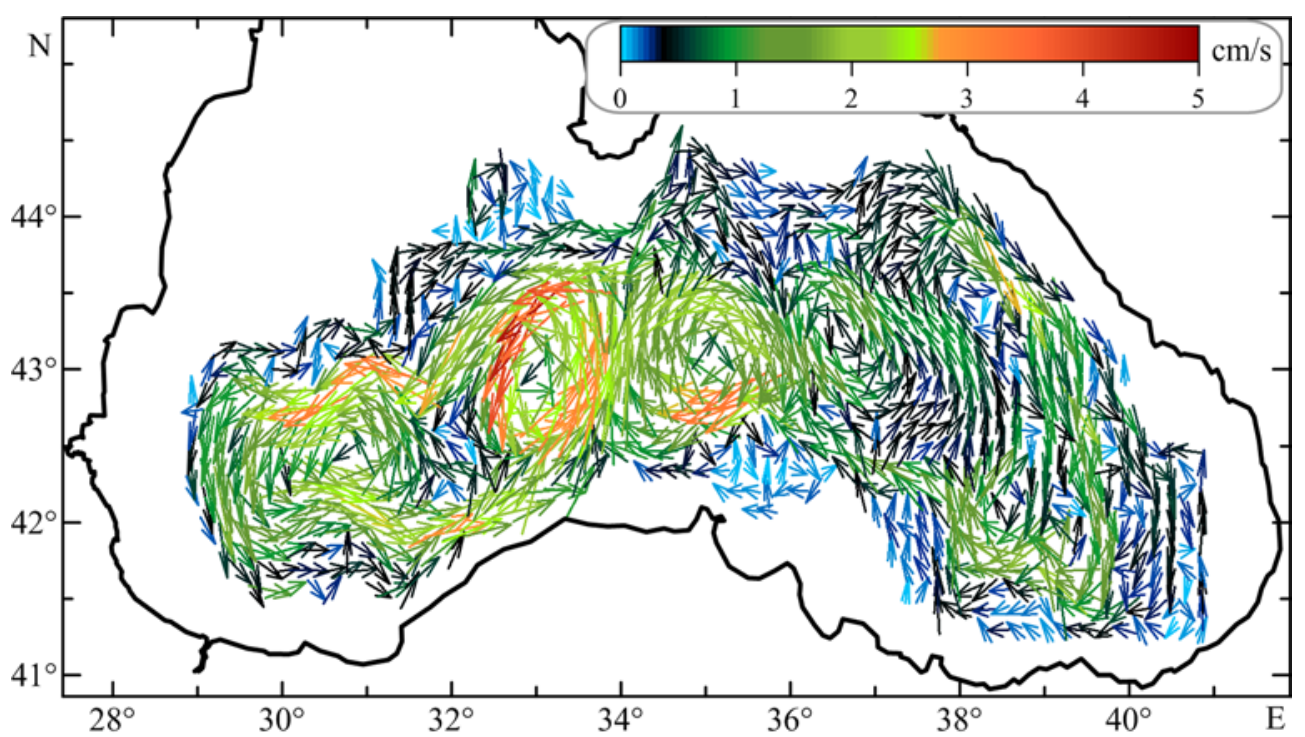

Fig. 1. Climatic currents of the Black Sea on May, 30 on 1500 m horizon (Experiment I)

Regional features of the field of currents in the north-eastern part of the Black Sea. Earlier in [7, 9] (in the North Caucasian coast near Gelendzhik at the depths of $300-350 \mathrm{~m}$ and below a narrow climatic current was found (Fig. 2). It existed from March to July and propagated south-eastward along the coast with a velocity of $2.5-4 \mathrm{~cm} / \mathrm{s}$ opposite to the Rim Current. The specified current has a length of about $70 \mathrm{~km}$ and a width of $10-20 \mathrm{~km}$ on these horizons. Analysis of the vertical velocities showed that in the area of Tuapse this current went down to 1200 $1400 \mathrm{~m}$, propagating south-eastward along the continental slope, and reached the Batumi anticyclone region. The current was not only defined by the numerical modeling but was also discovered during the field experiment at the SB SIO RAS polygon near Gelendzhik. Measurements were carried out on 17 - 19 June, 2011 on the traverse of the Gelendzhik Bay behind the continental slope at $44^{\circ} 28^{\prime} 17 " \mathrm{~N}$, 37 $56^{\prime} 14 " \mathrm{E}$ by Akvalog profiler [18]. The countercurrent existence the under the Rim Current in the $500-900 \mathrm{~m}$ layer with maximum velocities up to $3 \mathrm{~cm} / \mathrm{s}$ at a depth of $700-850 \mathrm{~m}$ was directly established.

To detail the study and to compare the modeling results with the in-situ data the currents maps were constructed for horizons 350, 400, 500, 600, ..., 1500, 1800 and $2000 \mathrm{~m}$ for every day of the climatic year. Then the time interval when the current appeared and disappeared at different depths in the north-eastern part of the sea was selected. It was confirmed that at an average by the depth this period was limited by March - July.

It is established that in Gelendzhik area on the horizons of $300-500 \mathrm{~m}$ the countercurrent appears in the first ten days of March. At the initial stage its velocities are $1-2 \mathrm{~cm} / \mathrm{s}$. By the end of the month, they increase to $3 \mathrm{~cm} / \mathrm{s}$ and in April reach $4 \mathrm{~cm} / \mathrm{s}$. Countercurrent is the most formed in June (Fig. 2). Since midJuly, it deepens and its velocities decrease to $0.5-1 \mathrm{~cm} / \mathrm{s}$ on these horizons. In August the countercurrent is found only in the area of Novorossiysk - Gelendzhik, and in September it disappears. In autumn the velocities vectors at these depths 
radically change their direction to the north-western one. On the horizons of 600 $800 \mathrm{~m}$ the countercurrent with velocities $0.5-1 \mathrm{~cm} / \mathrm{s}$ forms in early March and is rather unstable. Its structure is destroyed by the third ten days of March, recovering again about a week later. In mid-July the countercurrent is still strong (about $3 \mathrm{~cm} / \mathrm{s}$ on $600 \mathrm{~m}$ depth) but by the end of the month it disappears. We are to note that for all the considered horizons up to a depth of $1300 \mathrm{~m}$ in March - April there are some the currents velocity pulsations with a period from one to two weeks. For example, at the depth of $900-1200 \mathrm{~m}$ the countercurrent is formed during on March, $14-16$ and disappears on 20 - 21. Then it recovers on March, 27 - 28 and exists until mid-April, resuming again in the third week of this month. Current velocities on $900-1000 \mathrm{~m}$ horizons are about $1 \mathrm{~cm} / \mathrm{s}$ and on $1200 \mathrm{~m}$ horizon $2 \mathrm{~cm} / \mathrm{s}$. From May to mid-June the most developed and stable structure of the current non-broken by mesoscale eddies occurring seaward the continental slope is observed. Especially in this period it was important to get the measurement data to confirm its existence.

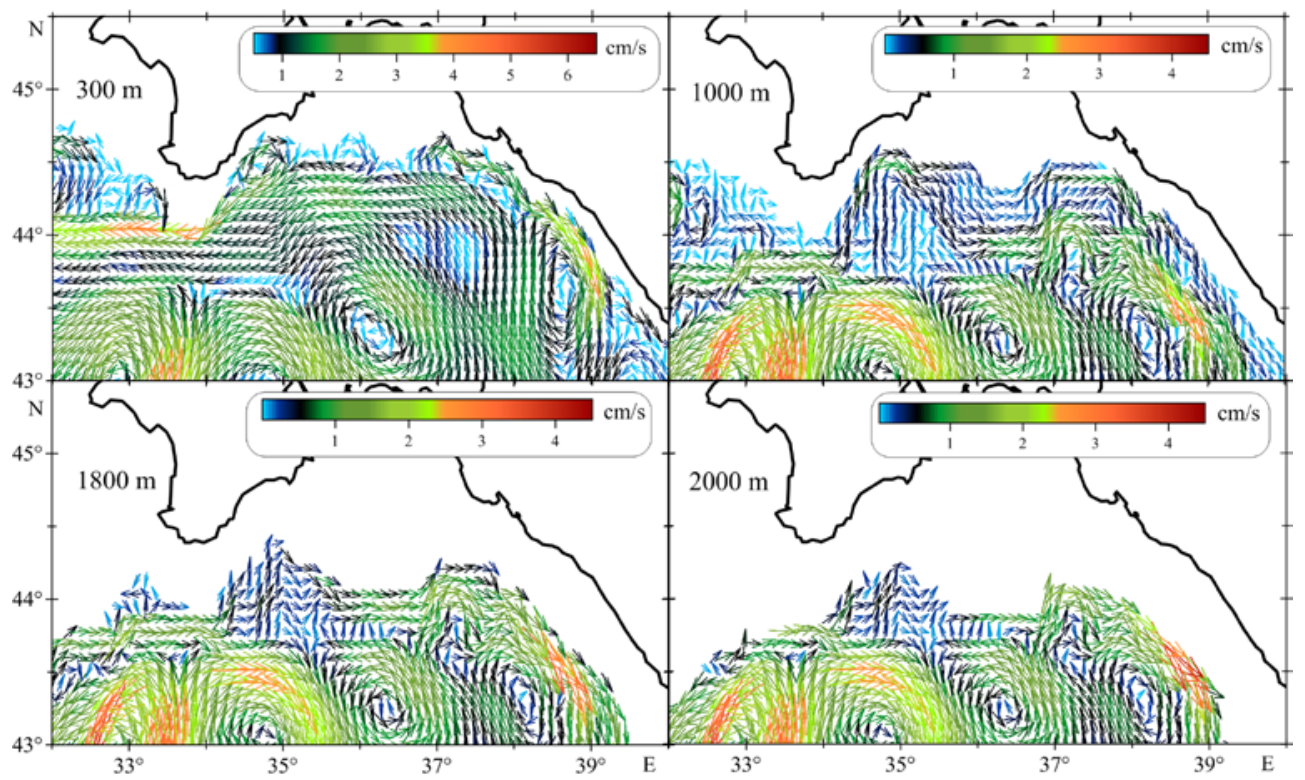

Fig. 2. Climatic currents of the Black Sea on July, 15 on 300, 1000, 1800 and 2000 m horizons (Experiment I)

On 1300 - $1400 \mathrm{~m}$ horizons the current is finally formed only by mid-May. Obviously, it is a part of the stream coming to the North Caucasian coast from the region of the Crimea. Its typical velocities are $1.5-2 \mathrm{~cm} / \mathrm{s}$ and grow up to $3-$ $3.5 \mathrm{~cm} / \mathrm{s}$ to the south-east of Gelendzhik. From the second ten days of July the currents structure destroys finally and doesn't restore at a given depth.

On $1500 \mathrm{~m}$ horizon the current is observed from mid-April until the beginning of July. The maximum velocities are about $3.5 \mathrm{~cm} / \mathrm{s}$ and in the area to the southsouthwest of Gelendzhik - about $2 \mathrm{~cm} / \mathrm{s}$. From the third ten days of July the velocities vectors in the considered area are starting to turn to the north-west and completely change their direction to the end of July. 
At $1800 \mathrm{~m}$ depth the countercurrent is observed in mid-May with mean velocity of about $1.5 \mathrm{~cm} / \mathrm{s}$ and the maximum ones $-2.5-3 \mathrm{~cm} / \mathrm{s}$. Since the end of June the restructuring of the velocity field starts to the south of the Crimean Peninsula. In the subsequent month the currents of the northern and north-eastern part of the Black Sea get the cyclonic direction.

Experiment II. Parameters. The second experiment was carried out using the same MHI numerical model [8] with the following parameters: horizontal grid step was $1.64 \mathrm{~km}, 27$ vertical levels were selected, and time step was equal to $96 \mathrm{~s}$. The coefficients of vertical turbulence were calculated by the Mellor-Yamada Level 2.5 parameterization [19]. The real atmospheric reanalysis data were used at the sea surface as the boundary fields. In the liquid boundaries (in river mouths and straits) temperature, salinity and current velocities were set similar Experiment I. The more detailed description of the problem mathematical statement, the initial and boundary conditions are given in [20].

Analysis of the modeling results. The analysis of the velocity fields obtained with high horizontal resolution taking into account the real atmospheric forcing also revealed the existence of anticyclonic current at depths below $1000 \mathrm{~m}$ in different years (Fig. 3). The following features were found out for all time intervals. The countercurrent was observed from end of May to August as sustained narrow stream localized in the north-eastern part of the sea between 34.5 and $41^{\circ} \mathrm{E}$. Its formation started in April to the south of Cape Meganom where a significant narrowing of the continental slope caused an increase of the currents velocity. The current width was $5-8 \mathrm{~km}$; its mean velocity was $7 \mathrm{~cm} / \mathrm{s}$.

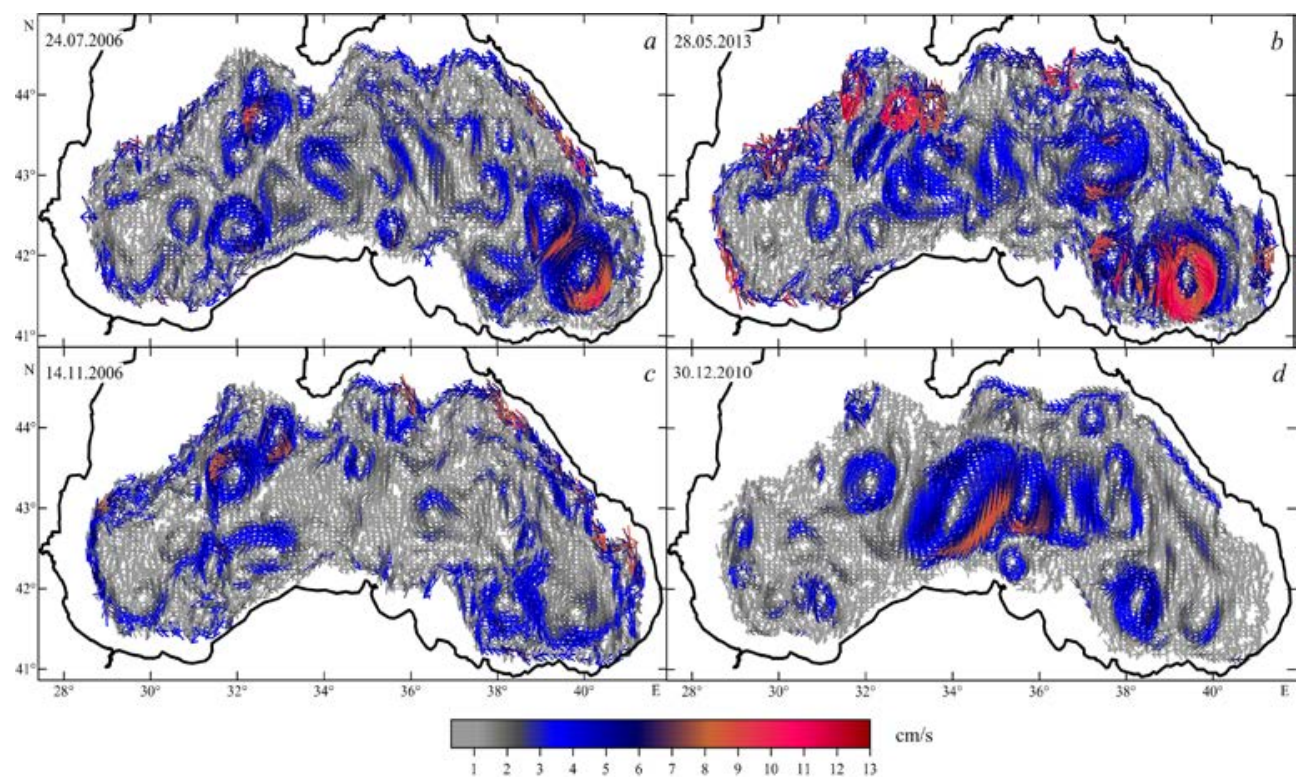

Fig. 3. Fields of the Black Sea currents on the $1000 \mathrm{~m}$ horizon (Experiment II)

The maximum velocities of $10 \mathrm{~cm} / \mathrm{s}$ were observed in July and August on the continental slope to the south of the Kerch Peninsula and to the south of the Abkhazian coast (Fig. 3, a). Separate narrow anticyclonic streams were fixed in the 
south-western part of the sea (Fig. 3, b). With increasing the depth in the northeastern part velocities of the countercurrent decreased to $4-5 \mathrm{~cm} / \mathrm{s}$. It should be noted that countercurrent reached maximum intensity during diminution of the velocity in the Rim Current core to $25-30 \mathrm{~cm} / \mathrm{s}$.

In $1500-1700 \mathrm{~m}$ layer the countercurrent is detected in the form of separate streams. The currents on the continental slope adjacent to the north-western shelf were most strongly marked in 2006 and 2013 on horizon of $1500 \mathrm{~m}$ (Fig. 4, a). North-eastward stream with velocities about $8 \mathrm{~cm} / \mathrm{s}$ was observed here from March to June. In April - May and August - September 2006 the south-westward current with width about $5 \mathrm{~km}$ and velocities in the core up to $7 \mathrm{~cm} / \mathrm{s}$ (Fig. 4, b) was reconstructed at $1700 \mathrm{~m}$ in the southern part of the sea.

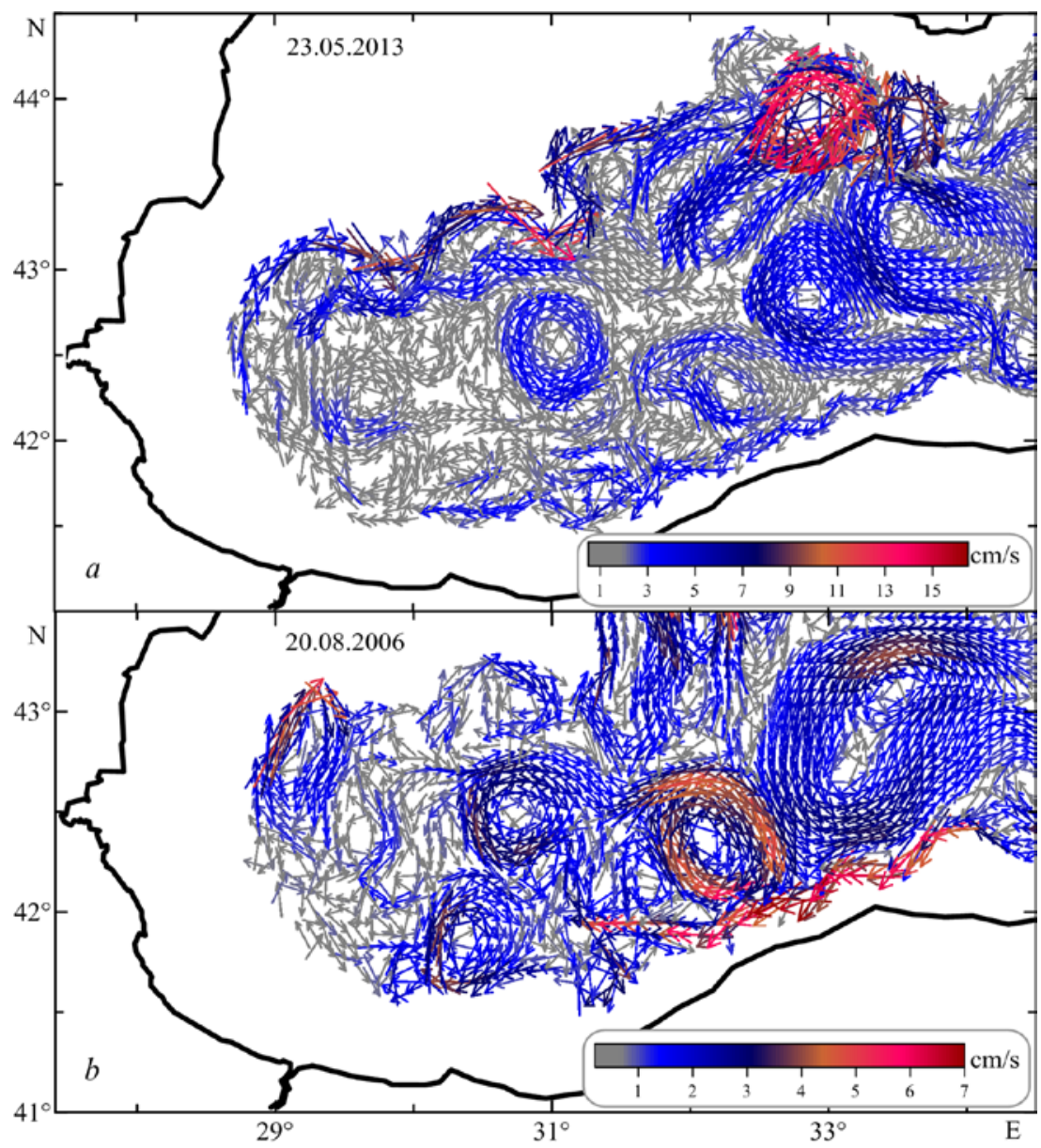

Fig. 4. The fields of currents on the horizons of $1500 \mathrm{~m}-a$ and $1700 \mathrm{~m}-b$ (Experiment II)

Analysis of the current maps on the horizons of 1000 and $1500 \mathrm{~m}$ in 2006 and 2010 showed that the countercurrent were periodically appeared in the cold season unlike the Experiment I. In November and December the countercurrent velocities reached $4-5 \mathrm{~cm} / \mathrm{s}$ on the continental slope near the North Caucasian coast and the stream width was increased up to $10-12 \mathrm{~km}$ in some areas (Fig. 3, $c, d$ ).

PHYSICAL OCEANOGRAPHY NO. 2 (2016) 
The Black Sea deep-water areas near the North Caucasian coast are the most representative for research of the countercurrent in $1000-1500 \mathrm{~m}$ layer. Taking into account the real atmospheric forcing in Experiment II the stream oppositely directed the Rim Current was marked here in all seasons. So stream velocity reached $4-5 \mathrm{~cm} / \mathrm{s}$ in February - March, the lifetime was 15 - 20 days, it stretch was from 100 to $150 \mathrm{~km}$. The destruction of this countercurrent is connected with the generation of mesoscale eddies with different vorticity sign. The countercurrent was intensified in May against the background of the eddy activity weakening. It width was increased to about $5 \mathrm{~km}$, the stretch - to $300 \mathrm{~km}$, the average currents velocity was increased to $7-8 \mathrm{~cm} / \mathrm{s}$. All the numerical experiments showed the most intensive countercurrent in the northeastern part in summer months. Its maximum width up to $6-8 \mathrm{~km}$ was observed to the south-west of Gelendzhik and Sukhumi. Maximum countercurrent velocities over $10 \mathrm{~cm} / \mathrm{s}$ were obtained in the last ten days of July 2006 and the second half of June 2013. The longest anticyclonic current was in July 2006 when it reached the area of Poti. In the autumn-winter season the countercurrent was registered in October and November 2006 and in December 2010. It was characterized by a short lifetime (about two weeks) and mean velocities of $3-4 \mathrm{~cm} / \mathrm{s}$.

Comparison with the reanalysis data. The obtained climatic fields were compared with the reanalysis data [12] calculated in [21]. Reanalysis of the Black Sea hydrophysical fields was carried out for the 1993 - 2012 year period using the MHI model. The calculations were performed on a $5 \mathrm{~km}$ horizontal grid, 38 vertical levels were considered. The fluxes of evaporation, precipitation, heat and wind stress derived from the ERA-Interim reanalysis [22] were used as atmospheric forcing.

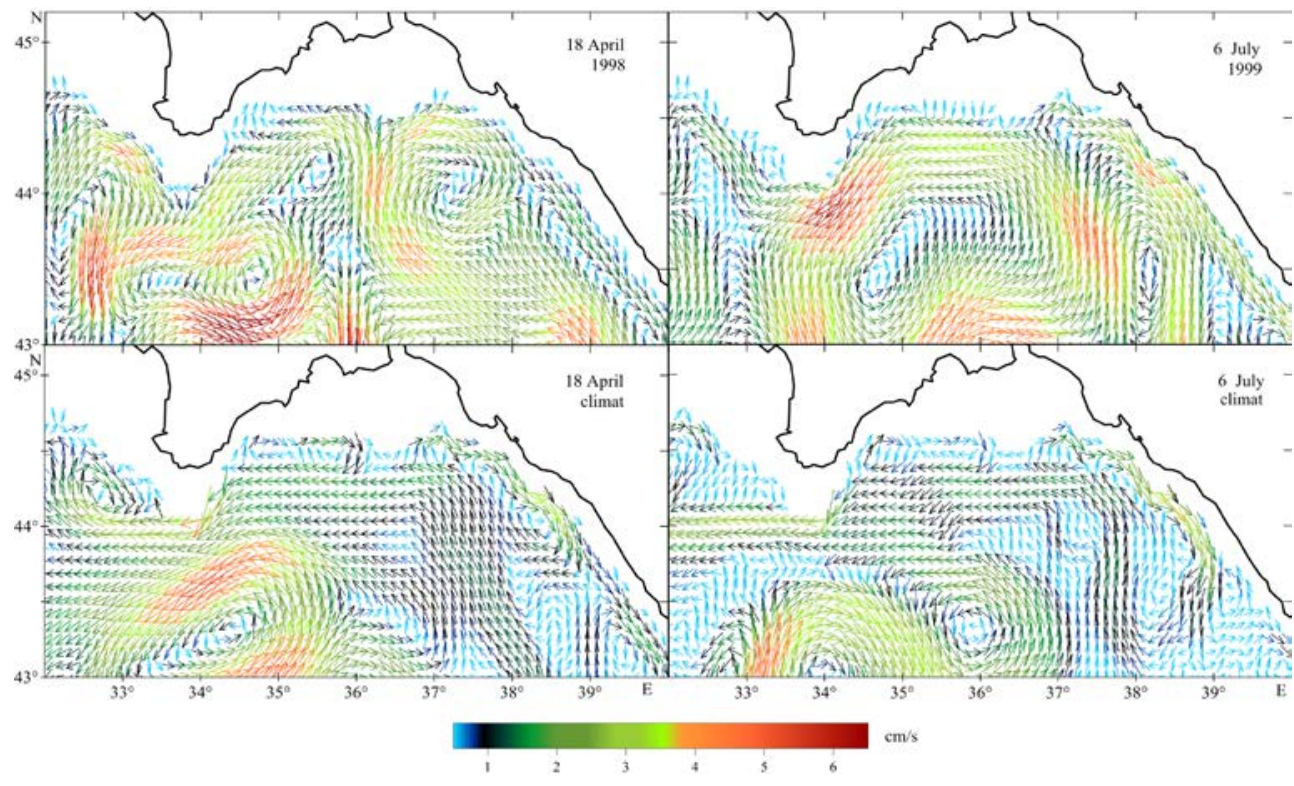

Fig. 5. Fields of the Black Sea currents: reconstructed from the reanalysis for April, 18, 1998 and July, 6, 1999 (above) and the climatic fields (below) 
The reanalysis data for 10 years (from 1993 to 2002) were selected to compare with modeling results. We considered the $400 \mathrm{~m}$ horizon where the countercurrent was observed from March to July in the north-eastern part of the sea according to Experiment I. On the basis of the aforementioned data the currents maps were constructed. We selected the years when the south-eastward stream was observed. The countercurrent was-reconstructed for 1993, 1998, 1999 and 2001. Fig. 5 shows synchronized currents maps resulted from the reanalysis (above) and calculations of the climatic fields in Experiment I (below). According to the reanalysis data the countercurrent was periodically observed from April to July, its width was 30 $35 \mathrm{~km}$, velocities $-1.5-4 \mathrm{~cm} / \mathrm{s}$, whereas in Experiment I the velocities reached $3.5 \mathrm{~cm} / \mathrm{s}$ and the width was up to $20 \mathrm{~km}$.

The question whether the considered stream along the North Caucasian coast is the result of the underlying anticyclonic countercurrent intensification due to the continental slope narrowing, or the boundary layer presence near the Black Sea eastern shore [23], or its appearance is due to other causes, requires the additional study.

Analysis of the measurements data. Regular CTD (conductivity-temperature-depth) measurements were considered as performed from R/V Akvanavt research cruises organized by SB SIO RAS in Gelendzhik [11]. As a rule, SBE-19 Plus CTD-probe was applied. Data were transferred to the vessel board in real time and processed using Sea-Bird Electronics software. Instrumental precision of the probe measurements was $0.005^{\circ} \mathrm{C}$ for temperature and $0.0005 \%$ for salinity, frequency of data digitizing $-4 \mathrm{~Hz}$. In shallow waters the probe submerged to the bottom and in the deep-sea zone - up to $500 \mathrm{~m}$ depth. Vessel measurements of temperature and salinity were used to restore the velocity fields by the dynamic method (in the geostrophic approximation). This method of currents calculation is approximate but gives quite successful results despite it doesn't take into account the local non-uniforms, non-stationary and baroclynic and friction effects. Its widespread use is due to the relative simplicity of practical tasks solution. In this study we applied the basic performance of the dynamic method [24].

The data processing imply the density profile $\rho(z)$ calculation at various stations till the depth of the "zero horizon" $z_{0}$ (300 m or more for the Black Sea [25]). Then, the density profiles are interpolated on a grid with uniform step and the construction of the density integrals $S D\left(r_{i}, z\right)$ was provided, where $r_{i}$ is the distance from the coastline, $z$ is the depth. The difference between the $S D\left(r_{i}, z\right)$ values calculated from measurements at the adjacent stations characterizes the horizontal gradient of pressure $\Delta P$ :

$$
\Delta P=g \int_{z_{0}}^{z} \rho\left(x_{2}, y_{2}, z\right) d z-g \int_{z_{0}}^{z} \rho\left(x_{1}, y_{1}, z\right) d z=g\left(S D\left(x_{2}, y_{2}, z\right)-S D\left(x_{1}, y_{1}, z\right)\right) \text {. }
$$

Alongshore velocity component profile in the direction perpendicular to the section trace was calculated as

$$
V_{n \perp}\left(\bar{r}_{2}-\bar{r}_{1}, z\right)=\left(g / f \rho_{0}\right)\left(S D\left(\bar{r}_{2}, z\right)-S D\left(\bar{r}_{1}, z\right)\right) /\left|\bar{r}_{2}-\bar{r}_{1}\right|,
$$

where $g$ was the acceleration of gravity; $f$ was the Coriolis parameter; $\rho_{0}$ was the average sea water density; $\bar{r}_{j}$ were the radius vectors of measurement points in the 
arbitrary rectangular coordinate system. $500 \mathrm{~m}$ depth was taken as the "zero horizon".

The common CTD-measurements trace type was "section" with the length of about 100 miles. The vessel performed one, rarely two sections in the perpendicular direction to the coast. The distance between the measuring stations was about $7-8$ miles. Also, the polygon-type surveys were often carried out (the measuring stations were placed at the nodes of a rectangular grid) and some others. In the present study we examined section-type survey data, while the deep part of the sea was captured. Typical map of such trace is shown in [11, Fig. 10].

In order to identify the features of the alongshore currents in the north-eastern part of the Black Sea the survey data for the 1997 - 2008 year period were processed using this method. The circulation features of our particular interest were found in July 1998 and in June 2004. Fig. 6 shows the maps of alongshore component of currents velocity perpendicular to the section. Red color indicates the north-western currents, the blue color - the south-eastern ones. It is shown that in late June - early July at depths of $250-300 \mathrm{~m}$ the countercurrents with velocities of up to $4 \mathrm{~cm} / \mathrm{s}$ are clearly distinguished, which corresponds to the direction, time interval and velocity values obtained in Experiment I (Fig 2, a).

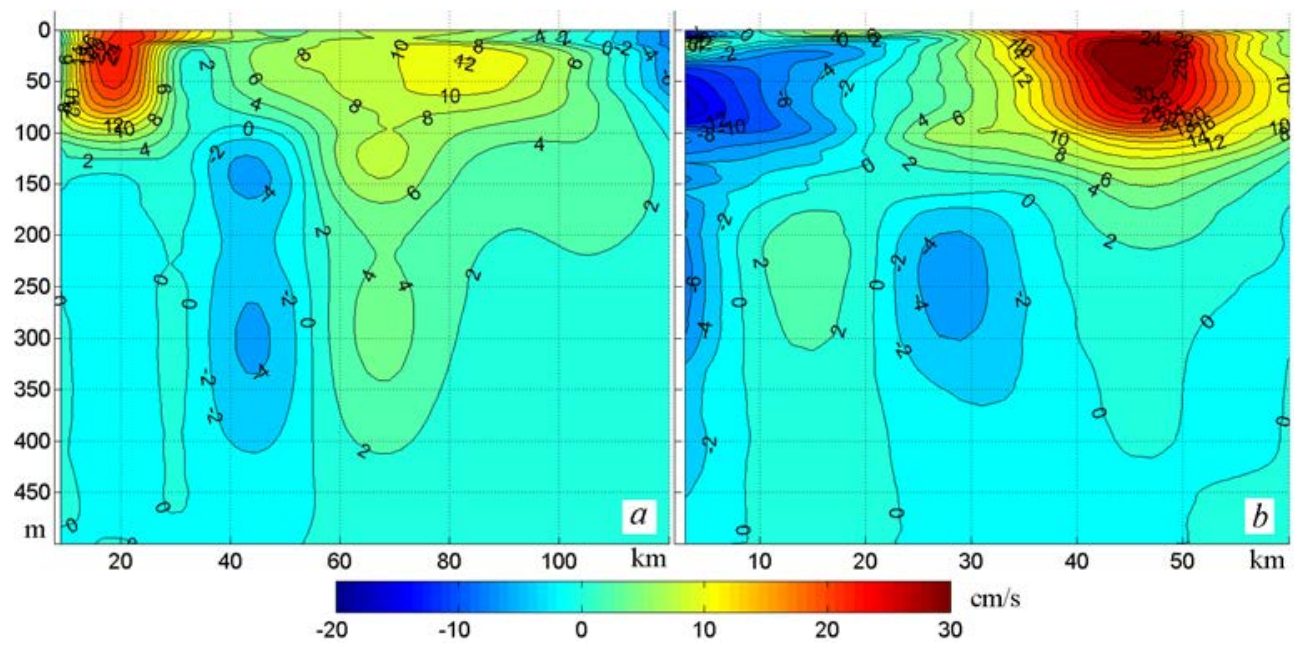

Fig. 6. Alongshore component of currents velocity perpendicular to the section trace: $a$ - July, $2-3$, 1998; $b$ - June, 24, 2004 (horizontal scale shows distance from the coast)

Conclusion. The comparison of the results of the Black sea currents numerical modeling below the main pycnocline under the influence of climatic forcing and real atmospheric forcing is presented. The analysis of some in-situ experiments on sub-satellite polygon of SB SIO RAS including deep-water measurements was carried out.

The climatic experiment results showed that an anticyclonic countercurrent existed at depths below $1000 \mathrm{~m}$ in spring and summer. It was formed near Bulgarian coast and reached the southern part of the Black Sea propagating eastward along the continental slope. That stream was also observed in the experiment with high resolution and the real atmospheric fields. Current velocities 
(an average of $7 \mathrm{~cm} / \mathrm{s}$ ) exceeded climate ones and the countercurrent was more narrow. Moreover, if taking into account the real atmospheric forcing the countercurrent was also reconstructed for winter season.

The results of our experiments are comparable to the existing estimates of mean deep currents velocities obtained in $[26,27]$ on the basis of the trajectories of floating buoys. In these studies the mean deep currents velocity was about $5 \mathrm{~cm} / \mathrm{s}$, but the amount of the buoy data did not allow detailing the features of the threedimensional deep-water circulation. In this case the use of mathematical models for the study of the deep Black Sea circulation is more than justified. The problem of provision by any contact data at depths greater than $300 \mathrm{~m}$ for the whole sea is extremely important. The database of SB SIO RAS contact measurements allows validating the model hydrophysical fields in the sub-satellite polygon area.

It was established that in the north-eastern part of the Black Sea in March July the south-east current directed opposite to the Rim Current is observed beyond the main pycnocline at depths of $300 \mathrm{~m}$ and deeper. The current continuity is periodically broken by the mesoscale eddies forming seaward the continental slope. According to the climatic fields calculation the stream width is about $20 \mathrm{~km}$ and the velocities reach $3.5 \mathrm{~cm} / \mathrm{s}$. Comparison to the reanalysis data for ten years on $400 \mathrm{~m}$ horizon confirmed the periodic generation of the countercurrent in the northeastern part of the Black Sea. On this horizon it was found in the spring and summer periods of 1993, 1998, 1999 and 2001. The countercurrent existence at depths of $300-350 \mathrm{~m}$ was also detected by the CTD-measurements in July 1998 and June 2004. Deep-sea ADCP-probing in June 2011 showed the presence of the countercurrent below the Rim Current in a layer of $500-900 \mathrm{~m}$.

Acknowledgements. The authors are particularly grateful to A.G. Ostrovskiy (P.P. Shirshov Institute of Oceanology, RAS) for ADCP-measurement results and P.N. Lishaev (Marine Hydrophysical Institute, RAS) for the reanalysis data provided.

The research was carried out under the support of the RFBR within the framework of the project No. 15-05-05423 A.

\section{REFERENCES}

1. Neumann, G., 1942, "Die absolute Topographie des physikalischen Meeresniveaus und die Oberflöchenstrumungen des Schwarzen Meeres”, Ann. D. Hydr. Und Marit. Meteorol., LXX, Heft. IX, pp. 265-282 (in German).

2. Bulgakov, N.P., Bulgakov, S.N., 1995, "Proyavlenie Protivotecheniya $v$ Chernom more $v$ polyah plotnosti vody i gidrostaticheskogo davleniya [Manifestation of the Black Sea countercurrent in the seawater density and hydrostatic pressure]”, Morskoy gidrofizicheskiy zhurnal, no. 4, pp. 63-76 (in Russian).

3. Bulgakov, S.N., Korotaev, G.K. \& Whitehead, J.A., 1996, "The role of buoyancy fluxes in the formation of a large-scale circulation and stratification of sea water: 1. Theory”, Izvestiya. Atmospheric and Oceanic Physics, vol. 32, no. 4, pp. 548-556.

PHYSICAL OCEANOGRAPHY NO. 2 (2016) 
4. Bulgakov, S.N., Korotaev, G.K. \& Whitehead, J.A., 1996, "The role of buoyancy fluxes in the formation of a large-scale circulation and stratification of sea water: 2. laboratory experiments”, Izvestiya. Atmospheric and Oceanic Physics, vol. 32, no. 4, pp. 557-564.

5. Petrenko, L.A., Kushnir, V.M., 2006, “Klimaticheskie pridonnye techeniya $v$ Chernom more [Climatic bottom current in the Black Sea]”, Ekologicheskaya bezopasnost' pribrezhnoy i shel'fovoy zon i kompleksnoe ispol'zovanie resursov shel'fa, iss. 14, pp. 477-486 (in Russian).

6. Arhipkin, V.S., Kosarev, A.N. \& Gippius, F.N., 2013, "Sezonnaya izmenchivost' klimaticheskikh poley temperatury, solenosti i tsirkulyatsii vod Chernogo i Kaspijskogo morey [Seasonal variability of temperature, salinity and water circulation climatic fields in the Black and Caspian Seas]”, Vestnik Moskovskogo universiteta. Serija 5 Geografija, no. 5, pp. 33-44 (in Russian).

7. Demyshev, S.G., Ivanov, V.A. \& Markova, N.V., 2009, “Analysis of the Black Sea climatic fields below the main pycnocline obtained on the basis of assimilation of the archival data on temperature and salinity in the numerical hydrodynamic model”, Physical Oceanography, vol. 19, no. 1, pp. 1-12.

8. Demyshev, S.G., Korotaev, G.K., 1992, "Chislennaya energosbalansirovannaya model" baroklinnykh techeniy okeana na setke $S$ [Numerical energy-balanced model of the baroclinic ocean currents on a C-grid]", Chislennye modeli i rezul'taty kalibrovochnyh raschetov techeniy $v$ Atlanticheskom okeane, Moscow, IVM RAN, pp. 163-231 (in Russian).

9. Demyshev, S.G., Ivanov, V.A. \& Markova, N.V., 2010, “Osobennosti glubinnoy klimaticheskoy tsirkulyatsii Chernogo morya [Peculiarities of the abyssal climatic circulation of the Black Sea]", Dokl. Natsional'noy akademii nauk Ukrainy, no. 7, pp. 96-100, (in Russian).

10. Demyshev, S.G., Knysh, V.V. \& Inyushina, N.V. [et al.], 2005, “Sezonnaya izmenchivost' $i$ transformatsiya s glubinoj klimaticheskikh gorizontal'nykh techeniy Chernogo morya po rezul'tatam assimilyatsii $v$ modeli novykh klimaticheskikh dannykh po temperature i solenosti [Seasonal variability and transformation with depth of climatic horizontal Black Sea currents based on the results of assimilation of new climatic temperature and salinity data in the model]”, Morskoy gidrofizicheskiy zhurnal, no. 6, pp. 28-45 (in Russian).

11. Zatsepin, A.G., Ostrovskii, A.G. \& Kremenetskiy, V.V. [et al.], 2014, "Subsatellite polygon for studying hydrophysical processes in the Black sea shelf-slope zone", Izvestiya. Atmospheric and Oceanic Physics, vol. 50, no. 1, pp. 13-25.

12. Korotaev, G.K., Lishaev, P.N. \& Knysh, V.V., 2015, "Metodika analiza dannykh izmereniy temperatury i solenosti Chernogo morya s ispol'zovaniem dinamicheskogo al'timetricheskogo urovnya [Technique of analyzing the Black Sea temperature and salinity measurement data using dynamic altimetry level]", Morskoy gidrofizicheskiy zhurnal, no. 2, pp. 26-42 (in Russian).

13. Pacanowski, R.C., Philander, S.G.H., 1981, "Parameterization of vertical mixing in numerical models of tropical oceans", J. Phys. Oceanogr., vol. 11, no. 11, pp. 1443-1451.

14. Korotaev, G.K., Demyshev, S.G. \& Knysh, V.V., 2000, "Three-dimensional climate of the Black Sea", Black Sea Ecosystem Processes and Forecasting, Erdemli, IMS METU, pp. 1-20.

15. Knysh, V.V., Demyshev, S.G. \& Korotaev, G.K., 2001, "Four-dimensional climate of seasonal Black Sea circulation", Rus. J. Numer. Analys. Math. Model, vol. 16, no. 5, pp. 409426.

16. 1991, "Gidrometeorologiya i gidrokhimiya morey SSSR. T. 4. Chernoe more. Vyp. 1. Gidrometeorologicheskie usloviya [Hydrometeorology and hydrochemistry of the USSR seas. Vol 4. The Black Sea. Iss. 1. Hydrometeorology conditions]”, Saint Petersburg, Gidrometeoizdat, 428 p. (in Russian). 
17. Belokopytov, V.N., 2004, “Termokhalinnaya i gidrologo-akusticheskaya struktura vod Chernogo morya [Thermohaline and hydrologic-acoustical structure of the Black Sea waters]”, Disertatsiya kandidata geograficheskih nauk, MHI NAN Ukrainy, 160 p. (in Russian).

18. Ostrovskii, A.G., Zatsepin, A.G. \& Soloviev, V.A. [et al.], 2013, “Autonomous system for vertical profiling of the marine environment at a moored station”, Oceanology, vol. 53, no. 2, pp. 233-242.

19. Mellor, G.L. \& Yamada, T., 1982, "Development of a turbulence closure model for geophysical fluid problems", Rev. Geophys. Space Phys., vol. 20, no. 4, pp. 851-875.

20. Demyshev, S.G., Dymova, O.A., 2013, "Numerical analysis of the mesoscale features of circulation in the Black Sea coastal zone", Izvestiya. Atmospheric and Oceanic Physics, vol. 49, no. 6, pp. 603-610.

21. Lishaev, P.N., Korotaev, G.K. \& Knysh, V.V. [et al.], 2014, “Vosstanovlenie sinopticheskoy izmenchivosti gidrofizicheskih polei Chernogo morya na osnove reanaliza za 1980 - 1993 gody [Reproduction of synoptic variability of the Black Sea hydrophysical fields based on reanalysis for 1980 - 1993], Morskoy gidrofizicheskiy zhurnal, no. 5, pp. 49-68 (in Russian).

22. Dee, D.P., Uppala, S.M. \& Simmons, A.J. [et al.], 2011, "The ERA-Interim reanalysis: Configuration and performance of the data assimilation system", Quart. J. Roy. Meteorol. Soc., vol. 137, no. 656, pp. 553-597.

23. Korotaev, G.K., 2005, “Intensifikatsya glubinnoj tsirkulyatsii v mezomasshtabnom basseine pod vliyaniem rel'efa dna [Intensification of a mesoscale basin deep circulation under the influence of the bottom topography]”, Morskoy gidrofizicheskiy zhurnal, vol. 15, no. 2, pp. 71-78 (in Russian).

24. Fomin, L.M., 1961, “Teoreticheskie osnovy dinamicheskogo metoda i ego primenenie $v$ okeanologii [Theoretical basis of the dynamic method and its application in oceanography], Moscow, Izdatel'stvo Akademii nauk SSSR, 192 p. (in Russian).

25. Titov, V.B., 1980, “O haraktere tsirkulyatsii i vertikal'noy strukture techeniy $v$ vostochnoy chasti Chernogo morya [About circulation and vertical structure of the currents in the Eastern part of the Black Sea]”, Okeanologiya, vol. 20, no. 3, pp. 425-431 (in Russian).

26. Korotaev, G., Oguz T. \& Riser, S., 2006, "Intermediate and deep currents of the Black Sea obtained from autonomous profiling floats", Deep-Sea Res. II, vol. 53, no. 17-19, pp. 19011910.

27. Gerasimova, S.V., Lemeshko, E.E., 2011, "Otsenka skorostey glubokovodnyh techeniy po dannym ARGO [Estimation of the deep-water current velocities according to the ARGO data]”, Sistemy kontrolya okruzhayushchey sredy, iss. 15, pp. 187-196 (in Russian). 